\title{
Forgotten Approaches to Care: The Human Being as Neighbour in the German-Jewish Tradition of the Nineteenth Century
}

\section{Elisabeth Conradi}

\section{Jewish Ethics in Germany}

In the United States and Europe, the ethics of care has achieved a prominent position among the variety of normative views in circulation. ${ }^{1} \mathrm{~A}$ major exception is the German-speaking world, which has for the most part ignored the topic and the feminist perspectives that often accompany it. ${ }^{2}$ Indeed, the entire subject area-along with the related concepts of benevolence, attention, donation, hospitality, and empathy-has hardly played a role in German university philosophy over the centuries, up to and including the present day. How to explain the German-speaking world's neglect? I would like to argue that philosophers advocating Jewish ethics in the nineteenth and early twentieth centuries planted the seeds

I would like to express my high regard to Dominic Bonfiglio for his competent and careful language revision from earlier drafts of this text into its final version.

E. Conradi $(\bowtie)$

Baden-Wuerttemberg Cooperative State University (DHBW), Stuttgart, Germany 
for these ideas but that their work was repressed by the Nazi regime and obscured by its long shadow, preventing a modern reception.

In 1935, Martin Buber (1878-1965) published Der Nächste, a collection of four essays on what it means to relate to other human beings as neighbours by the Marburg philosopher and neo-Kantian Hermann Cohen (1842-1918). In the introduction, Buber discusses when and under what circumstances assistance should be provided to others (1935, p. 7). He defends the need for positive duties against the widely held view in philosophy that restricts ethical duties to the ancient dictum 'Do no harm'. This position generally holds action to be mandatory only in very exceptional cases (Conradi 2016, pp. 54-58). Even a philosopher like Arthur Schopenhauer, who saw compassion as the driving force behind ethical behaviour, believed that the need must be acute and the emergency dire before action is required (2005, p. 101). For contemporary philosophers following Schopenhauer's lead, the main criteria for performing individual assistance are an expectation of a significant effect, a severe emergency, a limited duration of aid, and a minor effort required for assistance (Mieth 2012, p. 243). Buber focuses on two other aspects of positive duty: whether the recipient is a member of one's own collective and whether the recipient is spatially proximate. Buber emphasises that the person at the receiving end could be anyone and therefore no distinction should be made between neighbour, stranger, friend, acquaintance, and enemy. But he believes particular attention should be paid to any person who is within the helper's immediate sphere:

'Be loving to your fellow as to one who is like you', is written in the Scripture, and shortly thereafter, as if to avoid any misunderstanding at any time, through special highlighting: 'Be loving to a stranger as to one who is like you'. Rea, the fellow, is someone I am dealing with, whom I met just now, the human being so to speak, for whom I should be 'concerned' at this moment, whether he is of my own people or a foreigner. I should, literally translated, 'love him': turn towards him tenderly, show him love, practice love; namely as someone who is 'like me': in need of love such as I, in need of an act of love of a rea like me-as I know it just from my own soul. That this is to be understood in this way arises from the words following the second sentence: 'Because you've been strangers in the land of Egypt'or, as it says more clearly elsewhere: 'You know the soul of the stranger, 
because you've been strangers in the land of Egypt'. You know this soul and its suffering, you know what it needs, and therefore, those to whom it was once refused, deny them not! Let us dare, from there, to put the justification of the first sentence in words. Be loving to your fellow human being as to one who is like you-you know the soul of the co-human [Mitmensch], who is in need, so that one is loving to him, because you are people and you suffer yourself the plight of man. Such is a message of the 'Old Testament' (1935, pp. 6-7).

Buber stresses the equal ranking of human beings in one's proximity. For all of them, the same personal support is mandatory, regardless of whether they are neighbours, mere acquaintances, or strangers. Buber makes the impression that the act of assistance is less important than the act of turning our attention towards others. What ethical behaviour is truly about is the decency, attention, warmth, and kind-heartedness that accompany it. We should view others as in "need of love" [liebesbedürftig], we should "turn towards them tenderly" [liebend zuwenden], "show them love" [Liebe erzeigen], and "practice love to them" [Liebe antun] (1935, p. 6). ${ }^{3}$

Martin Buber was by no means alone in his focus on what it means to relate to other human beings as neighbours. In the long nineteenth century, religious philosophers, writers, and rabbinic scholars widely reflected on social justice, companionship, consolation, and cooperation. Around 30 texts written between 1837 and 1913 on this subject matter were recently republished under the title Nächstenliebe und Barmherzigkeit (Brocke and Paul 2015). Few of these texts were likely to have been written as contributions to contemporary philosophical debate. Many came in response to vehement attacks against the authors, with some critics even questioning their right to citizenship and societal belonging. What is more, the authors of these texts geared them towards lay readers in an effort to expand their knowledge and perhaps to equip them with arguments against common criticisms. The majority of these treatises were dedicated to defending Jewish ethical teachings against popular misrepresentation. They explicitly rebutted legends and obvious simplificationssuch as the claim that the code of conduct Jews followed among themselves was different from the one they followed among non-Jews - and rejected the mischaracterisation of Jewish ethical teachings as small minded and petty. Jobst Paul argues that Jewish ethics ties the institutional social 
justice with individual ethical requirements of benevolence and charity (Paul 2015, p. 12). "In view of the complexity and depth with which these themes are meaningful for and mould Judaism in its ethical core", he observes, "it is completely incomprehensible that precisely this ethical core ... became the ideological basis for hostility towards Jews" (2015, p. 13). But that is exactly what happened in the course of the nineteenth century: the process through which the Jewish minority had become equal citizens before the law was discredited. Underlying the calls for the revocation of Jews' citizenship and the criticisms of Jewish ethics were two interlocking myths. The first, Paul explains, was that "in Judaism, only a member of the brethren is considered a fellow human being. ... The Jewish view is supposed to be selfish and particular, that is, geared towards its own interests". The second was that "only Christianity has brought forth a universalist ... altruistic ethics of neighbour love, making Judaism obsolete" (2015, pp. 13 f.).

Hermann Cohen, in correcting such "misunderstandings" (1935d, p. 19), sought to elucidate the idea of Mitmenschlichkeit, or co-humanity, in the Jewish tradition (Sieg 1997, p. 252). In 1888, the Royal District Court of Marburg asked Cohen to provide an expert opinion on the following proposal: "The law of Moses is only valid from a Jew to another Jew; it has no bearing on Goyim, whom you may rob and cheat" (Cohen 1888 , p. 3). Hermann Cohen presented his answer in an essay titled "Neighbour Love in the Talmud" ("Die Nächstenliebe im Talmud") (1888, p. 1).

This paper was one of the four texts collected in Buber's Der Nächste. ${ }^{4}$ The editor's afterword (it is unclear whether it was written by Martin Buber or Margarete Susman ${ }^{5}$ ) contains a summary of the allegations critics directed against Jewish ethics in the late nineteenth century:

The main accusation against Judaism was that it was spiritually and practically surpassed by ... Christianity's unconditional neighbour love. Theologians and antisemites are in agreement on this point. Theologians like Rudolf Kittel and Franz Delitzsch concluded from it Christianity's morally superiority; antisemites concluded from it Judaism's inferiority. Vulgar antisemitism alleged and still maintains that Judaism's ethical principles applied only to Jews and urged immoral behaviour towards nonJews. (Cohen 1935a, pp. 82 f.) 
The afterword notes that Cohen's papers were directed against past arguments — the theologian Rudolf Kittel died in 1929-but in deciding to republish four of Cohen's texts in 1935, Buber was addressing his own contemporaries. The Protestant theologian Gerhard Kittel (1888-1948) ${ }^{6}$ published a brochure in 1933 titled "The Jewish Question" ("Die Judenfrage"), in which he invited Christians to endorse a piece of legislation enacted by National Socialists that permitted government authorities to fire Jewish professors, judges and other public servants at short notice (Kittel 1933). ${ }^{7}$ Kittel asked whether such a radical legislation was still justifiable from an ethical, Christian standpoint (1933, p. 7). ${ }^{8}$ His answer-the question was merely rhetorical—is clear: "We have established the unconditional demand that the struggle against Judaism must be led on the basis of an international and clear Christianity" (1933, p. 8). ${ }^{9}$ Kittel expressly denied "the equal social ranking of Jews and their basis civil rights" (1933, p. 20) and unambiguously legitimises the revocation of their citizenship by assigning them the status of "guest" ("Gast") and "stranger" ("Fremdling") (1933, p. 46).${ }^{10}$ In lending credence to his point, Kittel observed that over 3000 years ago Jews had lived as strangers in Egypt, and hence should continue to do so today. Grotesquely, Kittel tried to justify his position by quoting Mosaic law: "YYou shall give the poor his wages on the same day, before the sun sets: whether he belongs to your people, or whether he's a stranger who lives in your country and behind your gates' (5. Mos. 24,14; 27,19)" (1933, p. 57). ${ }^{11}$

Martin Buber immediately replied to these arguments (particularly the fallacious interpretation of the stranger's status in Mosaic law) in his 1933 "Open Letter to Gerhard Kittel", which appeared in the journal Theologische Blätter (Buber 2011). In the second edition of his brochure Kittel published a response to Buber, where despite the usual academic modus operandi he elected not to publish Buber's text alongside his own (1934, pp. 87-100). Buber's 1935 collection of essays by Cohen can be understood as a rejection of Kittel's absurd arguments. In fact, Gerhard Kittel did not think up his positions entirely on his own. Other theologians had already paved the way. For example, AdolfStoecker (1835-1909) published a collection of speeches where he notes that "modern Judaism seems to pose a major threat to German national life" (Stoecker 1880, p. 5). In 1880, Stoecker signed an "antisemite petition" submitted to the 
Prussian Prime Minister Otto von Bismarck. Its purpose was to undo the legal emancipation of the Jews of 1869, and demanded that the German nation rid itself of Jews' domination, limit their immigration, and exclude them from official posts (Conradi 2014, p. 231; Krieger 2003). Cohen rebutted arguments like these-specifically addressing those presented by the historian Heinrich von Treitschke [1879, p. 574] —in his 1880 "A Statement on the Jewish Question" (Cohen 2014). A few years later, Cohen published his expert opinion for the Royal District Court of Marburg, in which he discussed the treatment of strangers in the Jewish ethical tradition (Cohen 1888).

\section{Helping Those Nearby}

Philosophers tend to think that individuals are not obliged to help others if the need is small, if the expected effect of the aid only results in an improvement, if the assistance is continuous, or if the assistance is too taxing. Sometimes they allow the possibility of obligation if there is some kind of proximity to those in need. Onora O'Neill argues that some people are obliged to help others when they are socially close to them. Parents have 'special' (in contrast to 'universal') obligations towards their children: they are "held by some" and are merely "owed to specified others" (O’Neill 1996, p. 198). But the fulfilment of 'special' obligations is at the discretion of the individual, who decides who feels socially close, and whether and to what extent to fulfil them (O’Neill 1996, p. 251). Accordingly, this position leaves many questions open. One important question is, Whom to help?

For Hermann Cohen, the idea of co-humanity [Mitmenschlichkeit] suggests that the person receiving aid must be a fellow human beingNächster, someone near. But is a neighbour someone who is spatially near or socially near? Cohen's concept of the "human being as a neighbour" ("vom Menschen als dem Nächsten") gives no indication of pre-existing social proximity. Cohen does link co-humanity to a certain spatial closeness, however, and this is how Buber interprets Cohen's co-humanity (1935, pp. 6-7). For Buber, the neighbour is someone "with whom I have contact, whom I am just now meeting, the human being who concerns me at this moment" (1935, p. 6). Cohen talks about how the concept of 
the human being as neighbour and fellow human comes to be and reinterprets the "love of strangers" as a "creative moment" in this development $(1888$, p. 8). In this respect, there is no doubt for Cohen that the benevolence that accompanies co-humanity is directed at strangers and acquaintances in equal measure (Hollander 2012, p. 106). Whether someone counts as a 'co-human' [Mitmensch] depends only on whether the person is in difficulty and currently within one's own sphere. "Neighbour love, benevolence towards the stranger as defined by nationality and religion", he concludes, "is a commandment of Judaism" (1888, p. 8).

In addition to stranger love, Cohen stresses the basic requirement of social equality of human beings and their 'co-humans'. This kind of equality signifies parity and respect. In response to a comment by Naphtali Herz Wessely on the Third Book of Moses, ${ }^{12}$ Cohen writes: "He doesn't say I should love the neighbour like myself but renders it as love thy neighbour, he is like you. This is the new idea: that people are equal to each other as human beings, namely as children made in the image of God. From this stems the possibility of the duty of neighbourly love. The duty does not stipulate the degree of love-which would raise the suspicion that neighbourly love was self-help. It teaches the equality of people and from this, love is derived" (1935b, pp. $17 \mathrm{f}$.).

As I observed above, Buber does not explicitly characterise neighbourly love as a feeling, but he does speak of love. By contrast, Hermann Cohen explains the relationship of the human being and the co-human by way of disposition [Gesinnung], which he believes leads to action. This disposition is not felt; actions unfold [entfalten] from it. After some time, an awareness [Bewußtsein] arises that connects people and expresses itself as solidarity:

Neighbour love is a behaviour induced by a disposition towards co-humans, not the caution, protection, and defence against harm expected from them. All cultivation of a social life entails the unfolding of an ethical disposition. And compassion [Mitleid], which awakens people's suffering [Leiden], is less pain and passion than the dawning of moral awareness on behalf of the alliance of people, as a kind of force of nature that connects them. The disposition does not remain as an individual secret; rather, it expresses and is involved in the association of people (1935c, p. 8). 
From the first sentence of this long passage, it is clear that Cohen understands the active support of others as a positive duty, not a negative duty limited to the omission of harmful acts. Cohen's sense of ethics goes beyond the individual; it encompasses the awareness that people are connected and gives reasons for solidarity among them.

Leo Baeck is another thinker who considers social equality to be a fundamental ethical idea. Like Cohen, Baeck does not believe that compassion is a feeling: "In complete fidelity to the sense and the actual content of the word, he says: 'Love your neighbour, he is like you'. The whole emphasis is located on this 'like you'. It expresses the unity of all that is human, a unity that makes life on Earth meaningful and which means much more than the indefinite word love. The social idea of one humankind and one human right and not merely a fleeting feeling has formed this idea" (2007, p. 11 f.). For Leo Baeck, to treat your fellow human being decently and kind-heartedly is not a question of feeling or individual decision. It is required of the individual and structures social life and interaction.

The German rabbi and writer Ludwig Philippson also argues against describing co-humanity as a feeling. He sees the commandment of neighbour love as a social duty to take action. In Die That ("The deed") Philippson writes, "Religion has not just brought God closer to people; it has also brought people close to the fellow human being" (1845, p. 250). Philippson distinguishes between two types of ethics. He claims the biblical injunction "Thou shalt love thy neighbour as thyself" for Judaism and reads it as the active support of fellow human beings. The other type of ethics appropriated the concept of neighbour love, mimicked it, and "embellished it with many other words, with lots of beautiful words, with many lovely sayings; people revelled in the feelings of love, of peace-but where was the deed?" (1845, p. 250). Placing the biblical quote in the context of rabbinic writings, Philippson contrasts this second type of ethics with Jewish assistance of others [Wohltätigkeit], which he describes as "the most beautiful, the most noble side of neighbourly love, wherein the word has fully become deed" (1845, p. 250). Philippson sees two branches of Jewish Wohltätigkeit. Tzedaka, which is often translated as "charity", refers to the aid we give those in need (1845, p. 250). It is mainly a question of financial support and donations in five cases: (1) freeing innocent 
prisoners; (2) funding weddings that people otherwise could not afford; (3) feeding and educating orphans; (4) providing food and lodging for travellers who have been displaced, are sick, or have an urgent reason to leave their homes; and (5) treating the poor with a kind heart and comforting words (1845, p. 251). The second branch of Wohltätigkeit is the gemilut chassadim. It consists (1) in the participation in wedding celebrations; (2) in prayer for and visit of the sick; in (3) unpaid volunteer cleaning, clothing and burial of the dead; and (4) in the "consolation of the bereaved and grieving" (1845, p. 252).

Tzedaka and gemilut chassadim are key ideas in Jewish ethics. Gemilut chassadim can perhaps be considered as 'lending a helping hand' or as in person social engagement (Zeller 1997, p. 117). In the Jewish Encyclopaedia of 1928, the entry for gemilut chessed translates it as a "demonstration of love" and as an "active participation in the joys and sorrows of the fellow human being". But it also involves assisting others (Elbogen et al. 2008, p. 1007). Philippson explains that both tzedaka and gemilut chassadim are to be exercised according to the extent of one's own powers and abilities, yet no one is exempt: "And behold, this is the deed! This is deed and reality! This is not only a word and a sweet sensation, but a strong deed. The wise say that even the poor person who live on alms should sometimes give alms!” (1845, p. 252)

Gemilut chassadim is a central concept in understanding the notion of common humanity's place in Jewish ethics. In Samson Raphael Hirsch's (1808-1888) translation of the treatise Chapters of the Fathers [pirkei avot], a part of the Mishnah, it is said that "the world relies on three things: on the Torah, on worship, and on deeds of love". Hirsch's translation was published posthumously in 1895 . In his comment on the passage, he writes:

Torah: the knowledge of the divine truth and the divine will for our whole inner and outer self and world life; avoda: the duty of obedience to God in fulfilling His will with our whole inner and outer self and world life; gemilut chassadim: the selfless deeds of love for the salvation of fellow human beings. These three things make up and complete the human world and what it encompasses depending on size and type; where they are missing, and if they are missing, and to the extent that they are missing, there is a gap that cannot be replaced by anything, a part of being is missing. ... Without gemilut chassadim, humans lack the first part of being similar to 
God, and instead of bearing a likeness to God in saving and blessing their contemporaries, their hearts are frozen in senseless selfishness and hardness, and mankind lacks the bond of brotherhood and love, where the joy of life and happiness will thrive. In studying the Torah, human beings do justice to themselves; in avoda, to God; in gemilut chassadim, to their cohumans (1994, pp. 6f.). ${ }^{13}$

There are other interpretations of this line from the same decade. Isaak S. Bamberger (1863-1934) translates gemilut chassadim as "Wohltätigkeit" (contributing to wellbeing) and not, like Hirsch, as "selbstlose Liebestätigkeit" (selfless action out of love). Below Bamberger explains his decision:

The world rests on three things-the world in its entirety as well as each one was created for the purpose of performing these three things: the Torah; the study of the Torah for one's own spiritual perfection is a duty for a human being unto himself. Divine worship, first in the sacrificial service in the Tabernacle and in the holy Temple of Jerusalem, and since the destruction of the latter, in prayer. This brings with it obligations toward God. And assisting others, through personal bodily assistance (visiting the sick, funerals, consoling the bereaved, sharing the joy of bride and groom, making peace and the like) and support of the needy and poor, which is suited to the duties toward the fellow human being (1981, pp. 2f.).

The forms of personal assistance described here were no mere lip service. They were practiced by cooperative associations, known as hevrot in Hebrew (Auerbach 1969, p. 19). ${ }^{14}$ These non-profit groups had been active in large numbers and identifiable in every form in Europe since the sixteenth century (Farine 1973, p. 17; pp. 19f.; Baader 2001, p. 17).

Benjamin H. Auerbach, who wrote about the hevrot operating in Halberstadt in the nineteenth century, interprets such associations in the context of Jewish ethics:

It is a fact that the first characteristic sign of the presence of a pious Jewish community is the existence of associations in their midst; they secure within the community the three pillars on which, according to the words of the wise, the world rests: knowledge of the Torah, religious and human personal service, and giving alms (Torah, avoda, and gemilut chassadim); 
specifically in creating a special association for each branch of assisting others. These special associations can be more active within those three very large spheres of influence (1866, p. 128).

Auerbach points out that the encouragement of these tasks was not to be achieved primarily through financial contributions, but through collectively coordinated voluntary activity in person (Auerbach 1866, p. 128, n. 1). Auerbach names the groups active in Halberstadt around 1866. Members of one association visited the sick, supported them financially, and assisted the dying. There was a "bread distribution society", a "firewood distribution association" (Auerbach 1969, p. 28) that provided fuel to "the local Jewish poor during the four months of winter" (1866, pp. 128f.), and an association that supported transients and the "itinerant poor" during holidays (1866, p. 128, n. 1). There was a male "burial society" (1866, p. 226), founded in 1769 (Farine 1973, p. 30), that dealt "with the washing and cleaning of the dead, accompanies them to the cemetery, and prepares their tomb" (Auerbach 1866, p. 128). There was also a women's association whose members visited women and girls in need, read and discussed books with them, and performed funerals (1866, p. 129). Hirsch B. Auerbach (1901-1973) describes a Halberstadt women's association whose statutes go back to 1492 . It seems that this association was devoted primarily to the task of reading, and possibly to making clothes for the dead and visiting the sick (1969, p. 21). A soup kitchen was added at the beginning of the twentieth century (Auerbach 1969, p. 22).

All these activities are in line with the Jewish belief that people have a fundamental ethical obligation to their co-humans. Both in the Palestinian and Babylonian Talmuds, these obligations are defined as the exercise of mercy, hospitality, supporting the poor, visiting the sick, making peace, providing comfort for the grieving, and arranging funerals for the dead (Steppe 1997, pp. 81f.). Visiting the sick [bikkur cholim] also comprises the supply of food, the cleaning of the sick's room, the entertainment and consolation of the sick, and praying for them (Auerbach 1969, p. 27; Steppe 1997, pp. 81f.). Comforting, consoling, assisting, and, if necessary, nursing the sick, whether they are members of one's own community or outsiders, are part of religious duty in Judasim. Associations such as the hospital visit society [chevrat bikkur cholim] existed precisely for this purpose (Lewy 2008). 
Lina Morgenstern places these associations specifically in the context of the German women's movement. In her book charting the history of this movement, she also mentions numerous Jewish women's associations for learning and alleviating distress. Morgenstern was aware of 700 such entities (Lordick 2013, p. 11) dedicated to supporting the poor, the sick, new mothers, orphans, and needy children (Morgenstern 1893, p. 140 ff.). Some ten years later, Siddy Wronsky described the establishment of the Jewish Women's League: "Founded in 1904 in Berlin by Berta Pappenheim, on the occasion of the meeting of the International Women's congress, it seeks to merge Jewish women's associations in Germany (1928: 10 national and provincial associations, 32 local groups, 450 individual associations) with the aim of promoting cultural and social Jewish tasks for women and by women, each with an equal voice" (Wronsky 1929). For more than 30 years, the Jewish Women's League set itself cultural, social, and feminist objectives (Daemmig 2004). This alliance formed out of common beliefs shared by Jewish social reformers such as Lina Morgenstern, Bertha Pappenheim (Pappenheim 2015), Alice Salomon (Salomon 1901), Sidonie Werner, and Henriette Fürth. Despite the differences between them, they all wanted to combine the care of the elderly and sick with the creation of vocational training institutions and merge child welfare with their educational ideas. Clearly, their social commitment in this regard went far beyond any of the positive obligations defended by philosophers. Indeed, behind their political and scholarly pursuits was a belief in the need for Jewish social ethics.

\section{Political Practice and Ethical Belief}

Margarete Susman also stresses the idea of practical engagement in her essay "Revolution and Women" [Die Revolution und die Frau], published in December 1918 (1992). She wrote her essay in the aftermath of the First World War and the subsequent November Revolution. By this time, the major goal of the women's movement had been achieved: political suffrage for women was introduced on 12 November 1918. Susman criticises the passivity of most women towards the beginning of the war and urges them to become involved in the revolution. This put Margarete 
Susman in the proximity of radical feminists such as Lida Gustava Heymann and Helene Stöcker, who saw the introduction of women's suffrage as an admission of the collapse of male-dominated politics. By contrast, the speakers of the 'Federation of German Women's Associations' [Bund Deutscher Frauenvereine] issued a declaration in November 1918 that sought to justify the necessity of the war.

Susman begins her essay by asking why so few women in Germany were interested in politics, and discounts disenfranchisement and their lack of a public voice as reasons. She notes that suffragettes in England fought for their lives and the Germans only made fun of them, just as they had once distanced themselves from the "manly women" of the French and Russian revolutions. Although they possessed a "voluntary nature" arising from "self-sacrifice, silent goodness, pure heroism" (Susman 1992, p. 117), they lacked "freedom" in the sense of having made a "vital decision for or against what was happening" (Susman 1992, p. 118). German women's lack of political engagement was owing to the view that politics were "alien to the female character" (Susman 1992, p. 119); entering the political fray was tantamount "to a corruption of the purely human" (Susman 1992, p. 121).

But Susman argues that women are capable of being political and, given the politics of the time, their involvement was more needed than ever before. She proposes a politically active concept of the human opposed to what she criticises as "German inwardness" [deutsche Innerlichkeit]. A "ruinous inheritance of the great and inventive German metaphysics in uninspired times" (1992, p. 119), "German inwardness" is a situation in which individuals have no specific tasks but are occupied with general ideas. "Luther's isolation of individual conscience" was disastrous because the majority of Germans, especially women, were completely content "to be pure in their own eyes, untainted by personal guilt" (Susman 1992, p. 121). But women, Susman argues, applied the wrong criteria: "Women demanded from themselves that their actions be personal and good, righteous, helpful, and full of love. Any responsibility with regard to large life events as a whole was remote; their purpose here was that of serving faith. But faith can be moral only as religious behaviour; i.e. faith may only take place where our minds are faced with something basically inaccessible, something ultimate that we cannot fathom. 
For all other purposes, faith is weakness and guilt" (1992, p. 123). This situation was created because of inadequate education, and Susman pins the blame on Protestantism, as underlined by her reference to Luther. In contrast to such inwardness "of serving faith" ("des dienenden Glaubens"), she describes Jewish religiosity as one of action.

In recent years, efforts have been made in Germany to revive aspects of the themes discussed above-say, how Buber's principal of dialogue informs professional care (Schwerdt 1998, pp. 261-320) or the relationship between care of others and the writings of Levinas (Krause 2015, p. 248). Yet the question remains why topics such as assistance, hospitality, empathy, care, listening, and help were confined to the margins of German-language philosophy until well into the 1990s. One cause of this relative silence may be actions taken during the National Socialist regime: Martin Buber was forced to leave Germany; the Jewish Women's League was dissolved in 1938 (Daemmig 2004); books were removed from libraries and publicly burned; writings by rabbis (Brocke and Paul 2015) and Jewish social reformers were systematically withdrawn from circulation; propaganda was introduced aimed at undermining solidarity between majorities and minorities (Schmidbaur 2002, pp. 129f.). Consequently, the German-language thinkers who endorsed ideas of mercy, benevolence, hospitality, assistance, and help went mostly overlooked in the second half of the twentieth century (Conradi 2015b).

About 100 years after Hermann Cohen wrote about what it means to relate to co-humans as neighbours, the psychologist Carol Gilligan wrote an empirically based study that introduces the idea of care as a specific way of viewing the world (1988b, p. 8), a world in which people are related to each other through human connection (1982, p. 29). In this, Gilligan shares common ground with Herman Cohen, who believes that assisting others results from an awareness that is developed over time. She describes her 'care perspective' as 'thinking in relationships', seeing people as members in a network of relations "on whose continuation they all depend" (1982, p. 29-30). She interprets communication and care not so much as activities but as aspects of a viewpoint (Conradi 2015a). The emphasis on awareness, not feelings, distinguishes Gilligan significantly from Schopenhauer and probably also from Buber. Schopenhauer believes that awareness can prevent us only from committing harm; assistance itself is motivated by feeling (2005, 
p. 89). For attention and concern to be activated, "the distress" must be "great and urgent" (2005, p. 101). By contrast, Gilligan believes that action is needed when people are neglected and lonely (1988a, p. xviii); distance and detachment "constitute grounds for moral concern" (1987, p. 20). Buber, for whom despair is something that those who offer help know from their own experience, would agree (1935, p. 7). 'Thinking in relationships' is what allows us to recognise and identify such need in others. This point of view enables people to respond to depersonalisation in others by activating, cultivating, or repairing existing networks of communication (1987, p. 32).

Gilligan's 'thinking in relationships' goes far beyond what had previously been defended by the majority of philosophers as an ethical minimum: we must not only refrain from doing harm; we must improve others' situations. In this, she shares much with nineteenth- and early twentieth-century Jewish philosophy. Gilligan seems to agree with Buber that ethical commitment - whether conceptual or practical—applies first to those who are currently in one's own sphere. Yet she also agrees with Cohen that aid must not be limited to one's own social community; it ought to be extended to strangers as well. For Gilligan, social proximity between persons is constituted by 'thinking in relationships' through a type of anticipation; and it is established first and foremost through communicative engagement.

The ethics of care begins with human interactions - in assisting others effectively and in responding to human vulnerability and dependence. It starts off with everyday situations in which people assist others who require care for the foreseeable future, though their situation is not lifethreatening. The ethics of care regards care-receivers as partners as well as co-subjects by emphasising interactions between human beings.

\section{Notes}

1. The discipline in which the ethics of care is discussed depends on country and language: in the Netherlands it is an object of study mostly in nursing science, gender studies, medicine, and theology (Vosman 2016); in the United Kingdom and in Sweden, it mainly appears in the social sciences; in France and Italy, it has been consigned to philosophy. 
2. Even if the majority of German-speaking philosophers did not absorb the ethics of care I would like to highlight the work that had nevertheless been published. In Germany, there has been Andrea Maihofer's work on responsibility (Maihofer 1988) and Elisabeth Conradi's idea of attentiveness (Conradi 2001); in Austria, Christa Schnabl developed a socioethical theory of solicitude (Schnabl 2005, p. 439) and Herlinde Pauer-Studer has considered moral theory as it pertains to gender relations (Pauer-Studer and Nagl-Docekal 1993); in Switzerland, Annemarie Pieper has discussed the possibility of a feminist ethics (Pieper 1998) and Ina Prätorius has sketched out forms that a feminist ethics might take (Praetorius 1995). The care perspective has also appeared in debates about the increasing professionalisation in social work and nursing (Brückner 2008, 2010; Friese 2010; Schmid 2011). In the field of nursing, for example, Silvia Käppeli (2004) develops an idea of care from a theological point of view. In the area of social work, ethical approaches are occasionally taught that focus on the ethics of care (Großmaß 2006; Großmaß and Perko 2011, pp. 147-157; Noller 2007).

3. Buber leaves open whether he understands "love" as a deed, a feeling or an attitude.

4. Between 1894 and 1914 Cohen devoted three further essays to the question of what it means to relate to co-humans as neighbours.

5. The afterword is signed "M.S." but this might be a typo.

6. Gerhard Kittel was the son of Rudolf Kittel.

7. A significant number of the footnotes in the brochure cite Hitler's Mein Kampf and the political platform of the Nazi party ("Programm der NSDAP").

8. Kittel adds the following clarification: "For Christians, this truly brings up a serious question about the argument against the Old Testament and even the antisemitic attacks against the Jewish parts of the New Testament religion" (pp. 7 f). This passage, from the first edition of the brochure, was amended in the second edition (Kittel 1934): "For Christians, this truly brings up a serious question because for them, it is not only about humanity but about the problem of love, which is a fundamental requirement in Christianity and of which Paul the Apostle said that without it, everything else was nothing. On top of this, there is the multiple arguments of antisemites against the Old Testament; antisemitic attacks against the so-called Jewish components of the New Testament religion" (1934, p. 8). 
9. In his brochure, Kittel, a professor of protestant theology, muses, "you can try to exterminate the Jews (pogroms)" ("man kann die Juden auszurotten versuchen (Progrome)") (p. 13), but proposes an alternative: "You can resolutely and consciously preserve the historical fact of a 'strangeness' between peoples" ("man kann entschlossen und bewußt die geschichtliche Gegebenheit einer Fremdlingschaft unter den Völkern wahren") (p. 13).

10. Kittel writes, "The right of the guest must be clearly demarcated against that of the citizen" ("das Recht des Gastes muß allerdings in aller Deutlichkeit gegen das des Bürgers abgegrenzt sein") (1933, pp. 39 f). And "the status of the guest" must be "restored" ("entschlossen die Wiederherstellung des Gastzustandes herbeizuführen”) (1933, p. 38). "As soon as the principle of the right of strangers is absorbed into the (public) consciousness, it is absolutely clear and needs no further discussion that a guest is not the holder of a public office, and cannot be a civil servant" ("Sobald der Grundsatz des Fremdenrechtes ins Bewußtsein übergegangen ist, ist völlig klar und bedarf keinerlei weiterer Erörterung, daß ein Gast nicht Inhaber eines öffentlichen Amtes, also nicht Beamter sein kann") (1933, pp. 42 f.). Kittel mentions specific trades: "Once the idea of the guest is recognised and affirmed, it becomes obvious that a stranger can be neither a teacher of German youth nor a professor" " Ist der Gedanke des Gastes einmal anerkannt und bejaht, so wird ferner selbstverständlich, daß ein Fremdling im allgemeinen nicht Lehrer deutscher Jugend sein kann, auch nicht Hochschullehrer") (1933, p. 46).

11. Kittel cites a similar passage in the same text. See Kittel 1933, p. 78, n. 21.

12. The comment of Naphtali Herz Wessely (1725-1805) was published in 1781. Moses Mendelssohn (1729-1786) translated the five books of Moses into German. Under the title Sefer netivot ha schalom ("The book of the ways of peace"), the translations (using Hebrew letters) were published between 1780 and 1783 by George Friedrich Starcke (Boeckler 2015, p. XIII). Mendelssohn and several others supplied commentary to the text.

13. Samson Raphael Hirsch's commentary was part of the book Israel's Prayers ("Sidur Tefilot Yisra'el"), which on nearly every page includes prayers in Hebrew, prayers in German, and commentary on the prayers in German (Hirsch 1895). 
14. Hirsch Benjamin Auerbach (1901-1973) was a rabbi in Halberstadt from 1933 to 1938 and published on the history of the municipality. His great-grandfather Benjamin Hirsch Auerbach (1808-1872) was also a rabbi in Halberstadt, from 1863 to 1872, and, like his son, wrote about local history.

\section{References}

Auerbach, B. H. (1866). Geschichte der israelitischen Gemeinde Halberstadt. Nebst einem Anhange ungedruckter, die Literatur, wie die religiösen und politischen Verhältnisse der Juden in Deutschland in den letzten zwei Jahrhunderten betreffender Briefe und Urkunden. Halberstadt: Meyer.

Auerbach, H. B. (1969). Die Geschichte der alten Chewroth (wohltätigen Vereine) innerhalb der jüdischen Gemeinde in Halberstadt. Zeitschrift für die Geschichte der Juden, 6(1), 19-31.

Baader, B. M. (2001). Vom Rabbinischen Judentum zur bürgerlichen Verantwortung: Geschlechterorganisation und "Menschenliebe" im jüdischen Vereinswesen in Deutschland zwischen 1750 und 1870. In T. Adam \& J. Retallack (Eds.), Zwischen Markt und Staat. Stifter und Stiftungen im transatlantischem Vergleich (pp. 14-29). Leipzig: Leipziger Universitätsverlag.

Baeck, L. (2007 [1918]). Die Schöpfung des Mitmenschen. In Verband der deutschen Juden (Ed.), Soziale Ethik im Judentum (pp. 9-15). Frankfurt am Main: Kauffmann.

Bamberger, I. S. (1981). Kommentar. In I. S. Bamberger (Ed.), Pirke Aboth. Die Sprüche der Väter (pp. 3-145). Basel: Goldschmidt.

Boeckler, A. M. (Ed.). (2015). Die Tora nach der Übersetzung von Moses Mendelssohn. London: JVFG.

Brocke, M., \& Paul, J. (Eds.). (2015). Nächstenliebe und Barmherzigkeit. Schriften zur jüdischen Sozialethik. Köln: Böhlau.

Brückner, M. (2008). Kulturen des Sorgens über die Grenzen hinweg? Polis, 49, 9-28.

Brückner, M. (2010). Entwicklungen der Care-Debatte. Wurzeln und Begrifflichkeiten. In U. Apitzsch \& M. Schmidbaur (Eds.), Care und Migration. Die Ent-Sorgung menschlicher Reproduktionsarbeit entlang von Geschlechter- und Armutsgrenzen (pp. 43-58). Opladen: Budrich. 
Buber, M. (1935). Vorbemerkung. In H. Cohen (Ed.), Der Nächste. Vier Abhandlungen über das Verhalten von Mensch zu Mensch nach der Lehre des Judentums (pp. 6-7). Berlin: Schocken.

Buber, M. (2011 [1933]). "Offener Brief an Gerhard Kittel". In P. MendesFlohr (Ed.), Martin Buber. Werkausgabe. Band 9. Schriften zum Christentum (pp. 169-172). Gütersloh: Gütersloher Verlagshaus 2011.

Cohen, H. (1888). Die Nächstenliebe im Talmud: Ein Gutachten dem Königlichen Landgerichte zu Marburg erstattet. Marburg: Elwert.

Cohen, H. (1935a). Der Nächste. Vier Abhandlungen über das Verhalten von Mensch zu Mensch nach der Lehre des Judentums. Berlin: Schocken.

Cohen, H. (1935b[1894]). Über Wurzel und Ursprung des Gebots der Nächstenliebe. In H. Cohen (Ed.), Der Nächste. Vier Abhandlungen über das Verhalten von Mensch zu Mensch nach der Lehre des Judentums (pp. 11-18). Berlin: Schocken.

Cohen, H. (1935c[1910]). Gesinnung. In H. Cohen (Ed.), Der Nächste. Vier Abhandlungen über das Verhalten von Mensch zu Mensch nach der Lehre des Judentums (pp. 8-9). Berlin: Schocken.

Cohen, H. (1935d[1914]). Der Nächste. Eine kritische Untersuchung des biblischen Gebots der Nächstenliebe und seiner Mißdeutungen. In H. Cohen (Ed.), Der Nächste. Vier Abhandlungen über das Verhalten von Mensch zu Mensch nach der Lehre des Judentums (pp. 19-28). Berlin: Schocken.

Cohen, H. (2014 [1880]). Ein Bekenntniß in der Judenfrage. Berlin: Dümmler.

Conradi, E. (2001). Take Care. Grundlagen einer Ethik der Achtsamkeit. Frankfurt am Main: Campus.

Conradi, E. (2014). Eine Erörterung der "Antisemitenfrage" bei Constantin Brunner. In I.Aue-Ben-David, G. Lauer, \&J. Stenzel (Eds.), ConstantinBrunner im Kontext. Ein Intellektueller zwischen Kaiserreich und Exil (pp. 230-253). München: De Gruyter.

Conradi, E. (2015a). Redoing Care: Societal Transformation Through Critical Practice. Ethics \& Social Welfare, 9(2), 113-129.

Conradi, E. (2015b). Rekonstruierendes Quellenstudium und Nachrezeption: Wie die politische Ideengeschichte zu bereichern ist. In W. Reese-Schäfer \& S. Salzborn (Eds.), "Die Stimme des Intellekts ist leise". Klassiker/innen des politischen Denkens abseits des Mainstreams (pp. 85-111). Baden-Baden: Nomos.

Conradi, E. (2016). Die Ethik der Achtsamkeit zwischen Philosophie und Gesellschaftstheorie. In E. Conradi \& F. Vosman (Eds.), Praxis der Achtsamkeit. Schlüsselbegriffe der Care-Ethik (pp. 53-86). Frankfurt am Main: Campus. 
Daemmig, L. (2004). Kampf um Gleichberechtigung: Der Jüdische Frauenbund. HaGalil.com. Retrieved December 5, 2016, from http://www.berlinjudentum.de/frauen/jfb.htm.

Elbogen, I. et al. (2008 [1928]). Gemilut Chessed. In G. Herlitz \& B. Kirschner (Eds.), Jüdisches Lexikon. Ein enzyklopädisches Handbuch des jüdischen Wissens in vier Bänden. Band II, D-H (p. 1007). Berlin: Jüdischer Verlag.

Farine, A. (1973). Charity and Study Societies in Europe of the SixteenthEighteenth Centuries. I. Jewish Quarterly Review, 64, 16-47.

Friese, M. (2010). Die `Arbeit am Menschen`. Bedarfe und Ansätze der Professionalisierung von Care Work. In V. Moser \& I. Pinhard (Eds.), Care wer sorgt für wen? (pp. 47-68). Opladen: Budrich.

Gilligan, C. (1982). In a Different Voice: Psychological Theory and Women's Development. Cambridge: Harvard University Press.

Gilligan, C. (1987). Moral Orientation and Moral Development. In E. Kittay \& D. Meyers (Eds.), Women and Moral Theory (pp. 19-33). Totowa: Rowman and Littlefield.

Gilligan, C. (1988a). Prolog. In C. Gilligan, J. V. Ward, \& J. M. Taylor (Eds.), Mapping the Moral Domain (pp. vii-xxxviii). Cambridge: Harvard University Press.

Gilligan, C. (1988b). Remapping the Moral Domain: New Images of Self in Relationship. In C. Gilligan, J. V. Ward, \& J. M. Taylor (Eds.), Mapping the Moral Domain (pp. 3-19). Cambridge: Harvard University Press.

Großmaß, R. (2006). Die Bedeutung der Care-Ethik für die Soziale Arbeit. In S. Dungs, U. Gerber, H. Schmidt, \& R. Zitt (Eds.), Soziale Arbeit und Ethik im 21. Jahrhundert (pp. 319-328). Leipzig: Evangelische Verlagsanstalt.

Großmaß, R., \& Perko, G. (2011). Ethik für soziale Berufe. Paderborn: Schöningh.

Hirsch, S. R. (1895). Kommentar. In S. R. Hirsch (Ed.), Israels Gebete (Sidur Tefilot Yisra’el) (pp. 4-747). Frankfurt am Main: Kauffmann.

Hirsch, S. R. (1994 [1895]). Kommentar. In S. R. Hirsch (Ed.), Pirke Avot. Sprüche der Väter (pp. 1-123). Basel: Morascha.

Hollander, D. (2012). Love-of-Neighbor and Ethics Out of Law in the Philosophy of Hermann Cohen. In C. Wiese \& M. Urban (Eds.), GermanJewish Thought Between Religion and Politics: Festschrift in Honor of Paul Mendes-Flohr on the Occasion of His Seventieth Birthday (pp. 83-114). Berlin: De Gruyte.

Käppeli, S. (2004). Vom Glaubenswerk zur Pflegewissenschaft. Geschichte des MitLeidens in der christlichen, jüdischen und freiberuflichen Krankenpflege. Bern: Huber. 
Kittel, G. (1933). Die Judenfrage. Stuttgart: Kohlhammer.

Kittel, G. (1934). Die Judenfrage (2nd ed.). Stuttgart: Kohlhammer.

Krause, F. (2015). Die Sorge des Menschen. In O. Müller \& G. Maio (Eds.), Orientierung am Menschen. Anthropologische Konzeptionen und normative Perspektiven (pp. 241-255). Göttingen: Wallstein.

Krieger, K. (2003). Der "Berliner Antisemitismusstreit" 1879-1881. Eine Kontroverse um die Zugehörigkeit der deutschen Juden zur Nation. München: Saur.

Lewy, W. (2008 [1927]). Bikkur Cholim. In G. Herlitz \& B. Kirschner (Eds.), Jüdisches Lexikon. Ein enzyklopädisches Handbuch des jüdischen Wissens in vier Bänden. Band I, A-C (p. 1038). Berlin: Jüdischer Verlag.

Lordick, H. (2013). Mildtätigkeit, Solidarität und Selbsthilfe - Jüdische und Wohltätigkeits- und Bildungsvereine im 19. Jahrhundert. In U. Stascheit \& G. Stecklina (Eds.), Jüdische Wohltätigkeits- und Bildungsvereine (pp. 8-25). Frankfurt am Main: Fachhochschulverlag.

Maihofer, A. (1988). Ansätze zur Kritik des moralischen Universalismus. Zur moraltheoretischen Diskussion um Gilligans Thesen zu einer 'weiblichen' Moralauffassung. Feministische Studien, 6(1), 32-52.

Mieth, C. (2012). Positive Pfichten. Über das Verhältnis von Hilfe und Gerechtigkeit in Bezug auf das Weltarmutsproblem. Berlin: De Gruyter.

Morgenstern, L. (1893). Geschichte der deutschen Frauenbewegung und Statistik der Frauenarbeit auf allen ihr zugänglichen Gebieten. Berlin: Verlag der "Deutschen Hausfrauen-Zeitung".

Noller, A. (2007). Ethik der Achtsamkeit - Ethik der Menschenwürde: Sozialethische Anmerkungen zum Konzept Community Living. In T. Maas (Ed.), Community Living. Bausteine für eine Bürgergesellschaft (pp. 60-65). Hamburg: Alsterdorf.

O'Neill, O. (1996). Towards Justice and Virtue: A Constructive Account of Reasoning. Cambridge/New York: Cambridge University Press.

Pappenheim, B. (2015 [1899]). Frauenbewegung. In G. Wolfgruber (Ed.), Bertha Pappenheim. Soziale Arbeit, Frauenbewegung, Religion (pp. 92-97). Wien: Löcker. (Originally published under the pseudonym Paul Berthold). Pauer-Studer, H., \& Nagl-Docekal, H. (Eds.). (1993). Jenseits der Geschlechtermoral. Beiträge zur feministischen Ethik. Frankfurt am Main: Fischer.

Paul, J. (2015). Einleitung. In M. Brocke \& J. Paul (Eds.), Nächstenliebe und Barmherzigkeit. Schriften zur jüdischen Sozialethik (pp. 7-19). Köln: Böhlau. Philippson, L. (1845). Die That. In L. Philippson (Ed.), Siloah. Eine Auswahl von Predigten. Zur Erbaunng so wie insonders zum Vorlesen in Synagogen, die des Redners ermangeln (pp. 245-253). Leipzig: Baumgärtner. 
Pieper, A. (1998). Gibt es eine feministische Ethik? München: Fink.

Praetorius, I. (1995). Skizzen zur feministischen Ethik. Mainz: MatthiasGrünewald-Verlag.

Salomon, A. (1901). Die Arbeiterinnenbewegung. In H. Lange \& G. Bäumer (Eds.), Frauenbewegung und soziale Frauenthätigkeit in Deutschland nach Einzelgebieten. Handbuch der Frauenbewegung. Teil II (pp. 205-216). Berlin: Moeser.

Schmid, T. (2011). Was heißt es in Zukunft, eine solidarische Gesellschaft zu sein? In ÖKSA (Ed.), Langzeitpflege in einer solidarischen Gesellschaft Herausforderungen und Chancen (pp. 11-16). Wien: Info-Media.

Schmidbaur, M. (2002). Vom 'Lazaruskreuz' zu 'Pflege Aktuell'. Professionalisierungsdiskurse in der deutschen Krankenpflege 1903-2000. Königstein: Ulrike Helmer.

Schnabl, C. (2005). Gerecht sorgen. Grundlagen einer sozialethischen Theorie der Fürsorge. Freiburg im Breisgau: Herder.

Schopenhauer, A. (2005 [1840]). The Basis of Morality (A. B. Bullock, Trans.). Mineola: Dover.

Schwerdt, R. (1998). Eine Ethik für die Altenpflege. Ein transdisziplinärer Versuch aus der Auseinandersetzung mit Peter Singer, Hans Jonas und Martin Buber. Bern: Huber.

Sieg, U. (1997). Das Testament von Hermann und Martha Cohen. Stiftungen und Stipendien für jüdische Einrichtungen. Journal for the History of Modern Theology, 4, 251-264.

Steppe, H. (1997). “... den Kranken zum Troste und dem Judenthum zur Ehre ... ": Zur Geschichte der jüdischen Krankenpflege in Deutschland. Frankfurt am Main: Mabuse.

Stoecker, A. (1880). Erste Rede. In A. Stoecker (Ed.), Das moderne Judenthum in Deutschland, besonders in Berlin. Zwei Reden in der christlich-socialen Arbeiterpartei (pp. 3-19). Berlin: Wiegandt und Grieben.

Susman, M. (1992 [1918]). Die Revolution und die Frau. In I. Nordmann (Ed.), Das Nah- und Fernsein des Fremden. Essays und Briefe (pp. 117-128). Frankfurt am Main: Jüdischer Verlag.

Treitschke, H. v. (1879). Unsere Aussichten. Preußische Jahrbücher, 44, 559-576. Vosman, F. (2016). Kartographie einer Ethik der Achtsamkeit - Rezeption und Entwicklung in Europa. In E. Conradi \& F. Vosman (Eds.), Praxis der Achtsamkeit. Schlüsselbegriffe der Care-Ethik (pp. 33-51). Frankfurt am Main: Campus. 
Wronsky, S. (1929). Jüdischer Frauenbund. In G. Herlitz \& B. Kirschner (Eds.), Jüdisches Lexikon. Ein enzyklopädisches Handbuch des jüdischen Wissens in vier Bänden. Band III. lb-Ma (p. 471). Berlin: Jüdischer Verlag.

Zeller, S. (1997). Soziale Arbeit und Judentum. Sozialethische Elemente professioneller Sozialarbeit/Sozialpädagogik. Soziale Arbeit, 46(4), 110-123.

Open Access This chapter is licensed under the terms of the Creative Commons Attribution 4.0 International License (http://creativecommons.org/licenses/ by/4.0/), which permits use, sharing, adaptation, distribution and reproduction in any medium or format, as long as you give appropriate credit to the original author(s) and the source, provide a link to the Creative Commons license and indicate if changes were made.

The images or other third party material in this chapter are included in the chapter's Creative Commons license, unless indicated otherwise in a credit line to the material. If material is not included in the chapter's Creative Commons license and your intended use is not permitted by statutory regulation or exceeds the permitted use, you will need to obtain permission directly from the copyright holder. 